e-makâlât Mezhep Araştırmaları, VIII/2 (Güz 2015), ss. 121-150.

ISSN 1309-5803 | www.emakalat.com

\title{
İSLAM İTİKADINDA "KUTSAL"IN SINIRI
}

\section{Ali Yildız MUSAHAN*}

Öz

Kutsal inanan bir insan için yaşam kaynağıdır, sıra dışıdır, olağanüstüdür, gizemlidir. Kutsala inanan kişi, kutsal addettiği değere her zaman sayg1 ve ilgi duymakta, kutsaldan bir medet ummaktadır. Oysa Tanri'nın dışındaki kutsal olanlar, kutsallıklarını Tanrı'ya olan nispetlerinden alırlar. Bu mânada Tanrıya inanmayan insanların kutsallı inançları yoktur. İslam'da ise kutsalın merkezi ve kaynağı Allah'tır. Peygamberler dahil olmak üzere Allah nezdinde makbul olan siddıklar, şehidler, sâlihler, ayrıca insanların aşırı sevgi beslediği velî ve ermişler, hatta meleklerden hiçbirisi kutsiyetin mahiyetini oluşturan "yaratılmışlik üstü ve aşkın" özelliği taşımazlar. Günümüzde Müslümanların bir takım kişi, türbe ve değerleri aşırı yüceltmelerinin nedeni, bilgi ve tevhid kaynağ1 olan Kur'an'dan ve $\mathrm{Hz}$. Muhammed'in öğretilerinden uzaklaşmalarında yatmaktadır. Bazı Müslümanların türbelere ve velilerin, ermisslerin mezarlarina tapınma derecesine varabilen bağlılıkları, aynı cahiliye dönemi insanlarının putlara ve kahinlere tapınmalarına benzemektedir. Şah damarından daha yakın olan Allah'ı terk edip türbelerden ve bazı mübarek ziyaret yerlerinden bir yardim ve talepte bulunmak, tevhid dini olan İslam itikadına aykırı bir davranıştır. Allah kuluna tek başına kafi olup, O'nun yanında

\section{Abstract \\ The Limits of the "Sacred" in the \\ Islamic Belief}

The sacred is source of life for a believer, it is extraordinary, exceptional, and mysterious. The believer of the sacred is always respectful and $\mathrm{s} /$ he interested to the values which are considered as sacred by her/him, and s/he hopes for help from them. However, all sacred things other than God, get their sacredness from their relativeness with God. In this sense, unbelievers of God have no respect to sacred, and they do not have belief of sacredness. On the other hand, in Islam, God is in the center of the sacred and he is the source of the sacred. Including prophets, righteousness, martyrs, and saints and mystics who are respected and loved by people and even the angels do not have the characters of sacredness which are "supernatural and transcendental." Some people, shrines and values are exalted too much by some Muslims because Muslims gone away from the Qur'an which is source of knowledge and divine unity, and because they stayed away from teachings of Prophet Muhammad. Some Muslims' loyalty to shrines or tombs of saints and mystics is in level of worship, and this behavior is similar to behavior of people of the time of ignorance who worshiped idols and oracles. People abandoned the God who is "closer to him than [his] jugular vein," and they are seeking help from shrines, tombs and some holy visiting

Yrd. Doç. Dr. Iğdır Üniversitesi İlahiyat Fakültesi, aliyildizmusahan@gmail.com 
yardımcı kabul etmek, O'na ulassmak için bazı değerleri aracı kılmak en büyük günah olan şirke yol açma tehlikesini doğurmaktadır.

Anahtar Kelimeler: Kutsal, Kutsallaştırma, İslam, İtikat, Tevhid, Mekan, Değer spaces. This contradicts with Islam which is the religion of unity of God. God is sufficient for his believers, considering $\mathrm{He}$ has associates, and intermediate some values to reaching Him might cause polytheism which is cardinal sin in Islam.

Keywords: Sacred, Sacredness, Sanctify, Islam, Belief, Unity of God, Space, Value

\section{GİRIŞ}

\section{A. Kutsalın Tanımı}

Kutsal kelimesinin kökeni, Arapça k-d-s (ق د س) kelimesinden gelmekte ve "saadet, devlet, kudsiyet, uğur, baht, talih, mutluluk, hayır, bereket, mübarek" gibi anlamlara gelmektedir. Istılahî manas1 ise, güçlü bir dini sayg1 uyandıran, tapınılacak veya yolunda can verilecek derecede sevilen; bozulmamas1, dokunulmaması, karş1 çıkılmaması gereken, Tanrısal olan, ${ }^{1}$ şeklindedir.

İslam literatüründe Kutsal kavramı öncelikli olarak Allah'ın her türlü eksik ve noksan sıfatlardan uzak $^{2}$, mübarek, aziz, takdis edilen, saf, temiz $z^{3}$ gibi anlamları içermektedir. İslam düşüncesindeki "kutsallık" anlayışı diğer dinlerdeki "kutsallık" anlayışından farklılık arz etmektedir. Çünkü değerlerin kutsallığ tamamen sembolik olup, sembollerin kendileri ve özü asla mutlak kutsal değildirler. İslamiyet'te ise mutlak kutsal olan sadece Allah olup, yaratılmışlar

1 Türk Dil Kurumu, Türkçe Sözlük, Ankara, 1988, II Cilt, s. 939; http:/ / www.tdk.gov.tr/index.php?option=com_gts\&arama=gts\&guid=TDK.G TS.56bb43fa0383b6.10835889

2 İbn Manzur, Ebul-Fadl Cemaluddin Muhammed b. Murekkem, Lisanu'lArab, cilt VI, Beyrut, 1863, s.168; An-Naym, Arapça-Özbekçe İzahlı Büyük Lügat, Abdulla Kadiri Neşriyat1, Taşkent, 2003, s. 651

3 Firuzabadi, Muhammed b. Yakub Şirazi, Kamusu't-Muhîd, cilt 2, Misır, 1330, s.239 
ise, kanaatimize göre O'nun yaratmasından dolayı "mübarek" ve "muhterem"dir. İslam dünyasında genellikle 'kutsal' kavramı; kutsal kitap, kutsal topraklar, kutsal mekanlar, kutsal zatlar, kutsal görev, kutsal emanetler, kutsal ruh vb. gibi tamlamalarda kullanılmaktadir. ${ }^{4}$

Kutsal ve kutsallık kelimesinin yaygınlığ ile birlikte kutsal mefhumunun soyut bir şey olması, anlamının aç1k olmaması, kutsaldan tam olarak neyin kast edildiği konusu bir sorun olarak mevcudiyetini korumaktadır. Bu anlamda Allah'a isnat edilen bütün sıfatlar, isimler, melek, şeytan, cin, kıyamet, ahiret, haşir, mizan, sırat, cennet, cehennem gibi kavramlar aslında soyut olup, somut kavramlarla dile getirildiğinde kutsal bir değer kazanmaktadır. Öte yandan bir toplum tarafından sıradan sayılan inanç, şahıs, kavram, zaman vs. gibi değerler başka bir toplum için son derece saygın, muhterem ve uğrunda can verilen bir mefhum olabilmektedir.

Müslüman düşüncesinde genellikle 'kutsal' olmak ile bereketli, 5 muhterem, mübarek, pîr, saygin, hassas, namus, ehemmiyetli vs. gibi kavramlar birbirine karıştırılmaktadır. Bu tür belirsizliklerden dolayı bazen kutsala karşı sayg1 ve hürmet aşırı yüceltilmeye doğru gidebilmekte, itikadi yönden bazı sorunların meydana gelmesine mahal verebilmektedir.

\section{B. Kutsal ve Kutsallaştırma}

Kutsal, inanan bir insan için yaşam kaynağıdır, tarihsel bir fenomendir, sıra dışıdır, olağanüstüdür, gizemlidir. Kutsalı belirleyen en önemli unsur kişinin, kaynağı ilahi sayılan varlığa sevgi ve korkuya dayalı bir duyguyla bağlanma eylemidir. "Kendini her zaman

4 Bkz. Mustafa Çevik, "Kutsal'ın Anlam Alanı", Yüzüncü Y1l Üniversitesi Sosyal Bilimler Enstitüsü Dergisi, sayı 13/Bahar, Van, 2007, s. 131; Salih Özer, "İslam Düşüncesinde Kutsal (Zaman) Kavramı", İslami Araştırmalar Dergisi, cilt 18 , say 3,2005 , s. 314

5 İbn Manzur, Lisanu'l-Arab, cilt VI, s. 168; Ömer Gülen, "Tanr KavramınınKutsallaşmasi", Eskiyeni Dergisi, sayı 31, 2015-Güz, s. 89 
doğal gerçeklerden tamamen farklı bir gerçek olarak gösteren"6 kutsal, bir sir içermekte, insanda ve evrende olan başka bir şeye benzememektedir.

Dünyada kutsal görülen bir varlık, görünürde diğer türlerden farklı değildir. Kutsalı hemcinslerinden ayrı kılan şey, dini bir bakış açısına sahip kimselerin onları kutsal görmelerinden kaynaklanmaktadır. Çünkü, insanın kutsal mekanlarda bulunmasının temelinde kutsalı arama, yardım isteme inancı ve duygusu yatmaktadır. ${ }^{7}$

Müslüman düşüncesinde kutsal geceler, kutsal mekanlar bu tarz1 en iyi ifade eden birer dini fenomenlerdir. Mübarek sayılan mekanların, zamanların her biri, bir olaya işaret eder ve bir anlam taşır. Örneğin Kur'an'ın indirildiği kadir gecesi sıra dışıdır, olağanüstüdür ve diğer gecelerden farklıdır. Kutsal olan veya kutsallaştırılan mekanlarda insanlar kendilerini manen daha çok emniyette hissetmektedirler. Örneğin insanların türbe ziyaretleri esnasında yüce mertebe biçtikleri zatların yanında kendilerini emniyette hissettikleri gibi psikolojik yönden bir kurtuluş yolunda olduğu zannına kap1labilmektedirler.

İslam'da, kutsalın merkezi ve kaynağı Allah olup, O'nun isimlerinden birisi de Kuddûs'tur. Allah'in isimlerinden olan Kuddûs, Kur'an'da iki yerde geçmekte ${ }^{8}$ ve Allah'ın yaratılmışların sıfatlarından uzak, tertemiz, iyilik ve faziletlerle övülen bir varlık olması manasına gelmektedir. ${ }^{9}$ Bununla birlikte Kur'an'da kutsal mefhumuna

${ }^{6}$ Mirce Eliada, Kutsal ve Dindışı, çev. Mehmet Ali Kılıçbay, Gece Yayınları, Ankara, 1991, s. VIII

7 Türkiye'de yaygin olarak ziyaret edilen kutsal mekan örnekleri için bkz. Hüseyin İ. Yeğin, "Din Psikolojisi Açısından Kutsal Mekan İnsan İlişkisi", Harran Üniversitesi İlahiyat Fakültesi Dergisi, Y1l 17, sayı 27, Ocak-Haziran 2012, s. 61-65; Abdulkadir Kıyak, "Halk Dindarlığı Bağlamında Kutsal Mekan Anlayışı", Gümüşhane Üniversitesi İlahiyat Fakültesi Dergisi, cilt 1, sayı 2, $2 / 2012$, s. $166-178$

8 Haşr 59/23; Cuma 62/1

9 Gazzali, Ebu Hamid Muhammed b. Muhammed, el-Maksadu'l-esna fi şerhi Esmâilillahi'l-Husna, Matbaatus Sabah, Şam, 1999, s. 51; Sabuni Muhammed Ali, Safvetü't-Tefasir, Trc.Sadrettin Gümüş-Nedim Yılmaz, cilt VI, Ensar 
anlam yakınlığı bakımından 'El Hurmetü', 10 'el-Bereket', ${ }^{11}$ 'etTesbih', 12 'el-Kuds'13 gibi kelimeler zikredilmektedir.

Müslüman düşüncesinde genellikle kutsalın; İlahi yönü olan, Allah ile ilişkili olan gerçek kutsal değerler; insanlar tarafından abartılarak sonradan meydana gelmiş, kutsallaştırılmış değerler, şeklinde iki yönlü olduğunu görebilmekteyiz. İnsanlar tarafından kutsala izafe edilen mefhum ve nesneler arasında kutsal kitap, kutsal bilim, kutsal aile, kutsal evlilik, kutsal kazanç, kutsal görev, kutsal toprak, kutsal tarih; can, mal, din ve namus gibi kutsal değerlere rastlanmaktadır. ${ }^{14}$ Oysa, kutsal değer ile değeri kutsallaştırmanın tamamen farklı şeyler olduğu, kutsallaştırmanın insanlar tarafından meydana getirildiğinin farkına varılmaması sonucunda İslam dünyasında, birçok itikadi problemler ortaya çıkmaktadır. ${ }^{15}$ İslam inancının sarsılmaması, kutsala verilen değerin sınırlarını aşmaması için, öncelikle İslam'ın önem verdiği değerlerin iyi bilinmesi, değerler arasındaki farkların iyice ayırt edilmesi gerektiği, kanaatindeyiz.

Kur'an perspektifinden bakıldığında, peygamberler dahil olmak üzere Allah nezdinde makbul olan sıddıklar, şehitler, sâlihler, ${ }^{16}$ ayrıca insanların sevdiği mübarek şahsiyetler, hatta meleklerden hiç-

Neşriyat, İstanbul, 1992, s.388; Elmalılı Hamdi Yazır, Hak Dini Kuran Dili, Eser Neşriyat Yayınları, cilt VII, İstanbul, 1979, s. 4871

10 Hac 22/30 bkz. Kurtubî, Ebî Abdullah, Câmiu'l-Ahkâmi'l-Kur'ân, Daru'l-Fikr, trs., y.y, cilt 12, s.53-54

11 Araf 7/96; Hud 11/48, Lütufkar, en büyük, en yüce, en kutsal, kamil, kainatın tek yaratıcısı manasındadır. Bkz. Mâturidi, Ebu Mansur, Te'vilâtu'lKur'ân, thk. Ahmed Vanlığlu, Daru'1-Mizan Yayınları, İstanbul, 2005, cilt 5, s. 433

12 Rum 30/17 vd. Her türlü ayıplardan uzak ve her türlü eksiklikten münezzeh manasindadir.

${ }^{13}$ Haşr 59/23, Takdis edilmiş, pak, her türlü noksandan temiz ve münezzeh manasindadir.

${ }^{14}$ Ahmet Güç, "Kuran'da Kutsallık Anlayışı", Uludağ Üniversitesi İlahiyat Fakültesi Dergisi, say1 9, Cilt 9, 2000, s. 252

15 İlhami Güler, Sabit Din Dinamik Şeriat, Ankara Okulu Yayınları, 3. Bask1, Ankara, 2012, s. 75

16 Nisa $4 / 69$ 
biri17 kutsiyetin mahiyetini oluşturan "yaratılmışlık üstü ve aşkın" özelliği taşımamaktadır. Dolayısıyla kutsiyetin mecazî mânada da olsa insana izâfe edilmesi, onda bazı güç veya ilahi özelliklerin mevcudiyetini akla getireceğinden, itikadi açıdan bir takım sakıncalı problemlere yol açacaktır.

Makalemizde; bir değeri, insanı, türbeyi kutsallaştırmak söylemindeki kasdımız, kutsallaştırılmış olana doğrudan ibadet etmekten daha çok, Allah'ın emir ve yasaklarını geri plana atıp, kutsal değerin emir ve yasaklarına uymak; o şahsı, türbeyi ve değeri aşırı yüceltme eğiliminde bulunmak, şeklinde anlaşılmalıdır.

\section{KUR'AN'DA KUTSAL İLE İLGİLİ ÂYETLER}

Kur'an-1 Kerim'de 'kutsal' anlamında zikredilen, birçok âyet mevcuttur. Örneğin: "... Seni övgüyle yüceltip takdis eden bizler dururken..."18 âyetinde yaratıcıyı kutsal saymak manasında "nukaddisu" ifadesi geçmektedir. Yine kutsal manasında geçen Ruhu'l-Kudüs kavramı: "...Meryem oğlu İsa'ya mucizeler verdik. Ve onu Ruhu'1Kudüs ile destekledik..."19 şeklinde geçmekte, âyette geçen Ruhu'1Kudüs'un Cebrail olduğu konusunda çoğunluğun ittifakı bulunmaktadır. ${ }^{20}$

Kur'an'da mekan isimlerine örnek olarak, Allah Hz. Musa'ya "... Öyleyse artık pabuçlarını çıkar ve bil ki, sen kutsal vadi Tuvâ'dasın...!",21 yine İsrailoğullarına hitaben "Ey Kavmim! Allah'ın size (vatan olarak) yazdığı mukaddes yere girin ve arkanızı dönmeyin,

\footnotetext{
17 Nisa 4/172; Yunus 10/62-64

18 Bakara 2/30

19 Bakara 2/87; ayrıca bkz. Nahl 16/102; Mâide 5/110

${ }^{20}$ Bkz. Kurtubî, Câmiu'l-Ahkâmi'l-Kur'ân, cilt 2, s.24; Mâturidi, Te'vilâtu'l-Kur'ân, cilt I, s. 173

21 Tâhâ 20/12
} 
yoksa kaybedenlerden olursunuz"22 denilmesi de mekanın kutsallığ manasını taşımakta, ancak kanaatimizce burada bölgenin kutsal ve mübarek olmasının arkasındaki asıl sebep ilahi vahyin oraya tecelli etmiş olmasında yatmaktadır.

Kur'an'da takdis ve mukaddes kavramlarına yakın manada tesbih, ${ }^{23}$ uluvv, ${ }^{24}$ azîm/azametli, ${ }^{25}$ izzet $^{26}$, bereket/tebarek ${ }^{27}$ kavramlar1 da geçmektedir. Ulûhiyyet konusu üzerinde fikir beyan eden İslâm âlim ve düşünürleri tarafından benimsenen ve "Hiçbir şey O'nun benzeri değildir"28 âyetinde ifadesini bulan selbî sıfatların tamamı kutsiyet kavramının mâna ve muhtevasını pekiştiren beyanlardır.

Kur'an-1 Kerim, çeşitli sebeplerden dolayı amacını aşmış, hedefi ve sınırı yanlış belirlenmiş olan kutsalları düzeltip doğru bir 'kutsal değerler' inancını getirmiştir. Hz. Nûh'tan itibaren bütün peygamberler, Allah'tan başkasına kutsiyet atfedip ubûdiyyette bulunmamaları konusunda ümmetlerini uyarmış, peygamberlerin tebliğ ilkesinin temelini tevhid inancı oluşturmuştur. Çünkü Allah'tan başka herhangi bir varlığa kutsiyet kapsamında gönül bağlamak, insanın hem selim fitratı hem de şuurlu birer canlı olmanın sağladığı üstün konumu ile bağdaşmamaktadır.

Kur'an'da geçen tarih beyanlarından ve dinler tarihi verilerinden anlaşıldı̆̆1 üzere, tarih boyunca insanlar bazı tabiat varlıklarının zararlarından korunmak, bazılarından faydalanmak amacıyla türlü varlıklara, nesnelere, şahıslara, mekanlara, yaratıklara kutsiyet

\footnotetext{
22 Mâide 5/21

${ }^{23}$ Bakara 2/30; İsra 17/44; Enbiya 21/19, 20; Nur 24/41; Sâ'd 38/18,19

${ }^{24}$ Nisa 4/34; Neml 27/63; İsra 17/43; Hac 22/62; Naziat 79/24

25 Bakara 2/255; Şûra 42/4; Vâkıa 56/74,96; Hâkka, 69/33,52

26 Fâtır 35/ 10

27 Müminun 23/14

28 Şura 42/ 11
} 
nisbet etmiş, onlara insanüstü özellikler atfetmiştir. ${ }^{29}$ Tarihin çeşitli dönemlerinde hayvanlar bile kutsallaştırılmış, ay, güneş ve yıldızlara tapınılmış, ${ }^{30}$ gözle görülmeyen bazı varlıklara (cinler) Tanrılık izâfe edilmiş, ${ }^{31}$ melekler Allah'ın kızları diye nitelendirilmiş, ${ }^{32}$ Yahudiler Üzeyir'i, Hıristiyanlar Mesîh Îsâ'yı Allah'ın oğlu olarak kabul etmişlerdir. ${ }^{33}$ Bunların dışında İslâm öncesi Arap kavimlerinin çeşitli putlara-Allah'a yaklaştırıcı vesileler olarak-taptıkları bilinmektedir. Cahiliye Arapları tarafından başlangıçta Allah'a yaklaştırıcı veya aracı olarak telakki edilen herhangi bir varlık daha sonra ilahi/kutsal konumuna yükseltilmiştir. Puta tapan Cahiliye Arapları, putların şefaatçi olduklarını, ${ }^{34}$ kendilerini Allah'a yaklaştırdıkları için onlara ibadet ettiklerini ${ }^{35}$ belirtiyorlard1.

İnsanlık tarihinin yakın geçmişini incelediğimizde, aslında ve özünde tevhid inancina, monoteist bir dine mensup olan Yahudi ve Hıristiyanların, belli bir zaman geçtikten sonra başta Üzeyir ve Îsâ gibi tebliğle görevli kılınmış peygamberleri insanüstü varlıklar şeklinde kutsallaştırdıklarına şahit olmaktayız. Kur'ân-1 Kerîm onların bu tutumunu kâfirlerin telakkisine benzetmekte ve kendilerini ağır bir şekilde eleştirmekte, onlara doğru yolu tavsiye etmektedir. ${ }^{36}$

\section{KUTSAL DEĞERLERIN TÜRLERİ}

\section{a. İnsanın kutsallaştırılması}

Kutsalın tezahür ettiği peygamberler, rahipler, cemaat önderleri, şeyhler, mollalar, mezhep imamları ve siyasi liderler toplumları ar-

\footnotetext{
${ }^{29}$ Günay Haral, "İslam'da Kutsiyet" maddesi, TDV İslam Ansiklopedisi, cilt 26, 2002, s. 497

30 Fussilet $41 / 37$

${ }^{31}$ Saffat $37 / 158$

32 Saffat 37/149-155

33 Tevbe $9 / 30$

34 Yunus $10 / 18$

35 Zümer 39/3

36 Tevbe 9/30-31
} 
kalarından sürükleyen önderdirler. ${ }^{37} \mathrm{Bu}$ manada Kur'an'da zikredilen; "Yahudiler, Üzeyir Allah'ın oğludur, dediler. Hıristiyanlar Mesih (Îsâ) Allah'ın oğludur, dediler. Bu onların ağızlarıyla geveledikleri sözlerdir. Onların bu sözleri daha önce kafir olmuş kimselerin sözlerine benziyor. Allah onları kahretsin!"38 âyetinde belirtildiği gibi Üzeyir'in ve İsa'nın Allah'ın oğlu olduğuyla ilgili iddialara Kur'an şiddetle itiraz etmekte ve bu iki insanın insanüstü varlıklar gibi kutsallaştırılma düşüncesine karşı çıkmaktadır. Öte yandan $\mathrm{Hz}$. İsa'nın annesi Hz. Meryem de kutsallaştırılan insanlardandır. ${ }^{39} \mathrm{Oy}-$ sa, Kur'an herkesin anlayabileceği üslupla açık ve kesin cevap niteliğinde, Meryemoğlu Îsâ'nın sadece bir peygamber olduğunu, annesinin dürüst, inançlı ve namuslu bir anne olduğunu, her ikisinin de insanlar gibi yiyip içtiğini, diğer bir ifadeyle beşer üstü varlık şeklinde düşünülmemesi gerektiğini vurgulamaktadır. Hz. Îsâ bir insan olarak, Allah'ın verdiği felaketleri, mal, can bakımından musibetleri ve zararları verebilecek bir güce sahip değildir. 40

Kur'an'da kendi kendini kutsallaştıran Firavun ${ }^{41}$ ve Nemrud ${ }^{42}$ gibi kendini Tanrı ilan eden bir takım şahıslardan da bahsedilmekte, kimisinin kendi kendini kutsallaştırmasını, kimisinin ise insanlar tarafından kutsallaştırılmasını eleştirmekte ve bu durumu reddetmektedir. Çünkü tevhid inancinda Allah'tan başka kutsal yoktur. Tek kutsal varlık Allah'tır. ${ }^{43}$ Kur'an âyetlerinde Hz. Muhammed'in de bir insan olduğu vurgulanmakta, önceki din mensuplar1nın düştüğü hataya müslümanların düşmemesi için uyarı niteliğinde tavsiyeler edilmekte, peygamberleri aşırı yüceltmenin sakıncaları

\footnotetext{
37 Bkz. Şahin Ahmetoğlu, "İslam Mezhepleri Tarihinde Karizmatik Liderlik Anlayışı: Hz. Ali örneği", Milel ve Nihal: İnanç, Kültür ve Mitoloji Araştırmaları Dergisi, cilt 7, say1 3, Eylul-Aralık 2010, s. 168

38 Tevbe $9 / 30$

39 Bkz. Mâide 5/72

40 Mâide 5/76

${ }^{41}$ Bkz. Şuarâ 26/18-29; Kasas 28/38-42

42 Bakara 2/258

${ }^{43}$ Mâturidi, Ebu Mansur, Kitâbu't-Tevhid, thk. Muhammed Aruçi, T.D.V. Yayınlar1, Ankara, 2003, s. 37-40
} 
konusunda tenbihlerde bulunulmaktadır. ${ }^{44} \mathrm{~Hz}$. Muhammed'in Allah'tan vahiy alması ve insanlara tebliğ ulaştırmasının dışında, diğer insanlardan hiçbir farkı olmadığını Kur'an şöyle ifade etmektedir: "De ki, ben de sizin gibi bir insanım, ancak bana İlahınızın tek bir İlah olduğu vahyediliyor". 45

Herhangi bir kişiye karşı beslenen aşırı sevgi ve hayranlık onu mecazi bir kutsallaştırmaya kadar götürebilir. Aşırı sevilen ve sayılan birisinin emirlerine, yasaklarına itirazsız itaat etmek de ona yücelik atfetmek demektir. Bu şekilde davrananlar, sayg1 ve hayranlik duyduğu birisini velinimeti olarak tanıyarak, onun sevgisini hareket prensibi edinebilir. Böylece Allah'ın rızasını düşünmeden önce onun rızasını elde etmeye çalışır bir duruma gelebilir. ${ }^{46}$

Allah, Hz. Muhammed'den sadece kendisine yönelmesini ve kendisini tesbih edip yüceltmesini isterken ${ }^{47}$ Müslümanların; velileri, zatları, ermişleri hayattayken veya öldükten sonra aşırı yüceltmeleri ve itikatta belirtilen kutsallık sınırını aşarak saygı göstermeleri, hatta bazı zamanlarda onlardan yardım istemeleri, dualarının kabul edilmesi için Allah ile aralarında vesile olmalarını istemeleri, kanaatimizce Allah'ın emirlerine, O'nun birliğine ve vahdaniyet sıfatına kesinlikle aykırı bir durum teşkil etmektedir.

\section{b. Kutsal Mekanlar}

Kutsal mekan ve kutsal dışı mekan ayırımı, bütün dinlerde mevcut olan bir ayırımdır. Kutsal mekanların kutsal kabul edilebilmesi için mekanın bünyesinde icra edilen ayinlerin, ritüellerin, kurbanların, ibadetlerin çok büyük bir önemi vardır.

\footnotetext{
${ }^{44}$ Kehf 18/110; ayrica bkz. Kurtubî, Câmiu'l-Ahkâmi'l-Kur'ân, cilt 11, s.69-70; Mâturidi, Te'vilâtu'l-Kur'ân, cilt 9, s.113-114

45 Kehf 18/110; Fussilet 41/6; Ayrica bkz. İbrahim 14/10-11; Enbiya 21/3; Müminun 23/24,33; Şuara 26/154, 186; Yasin 36/15

46 Suat Yıldırım, Kuran'da Uluhiyet, Kayıhan Yayınları, İstanbul, 1987, s. 298

47 Müzemmil 73/8
} 
Mekan ve bölgelerin kutsal olması ile ilgili Kur'an'da birçok âyet zikredilmektedir. Kur'an'da kutsal mekanlarla ilgili geçen âyetlerden hareketle, kutsal mekanın diğer mekanlardan ayrıştığını, kutsal mekanların maddî ve mânevi lekelerden, putlardan, müşriklerden temizlenmesi gerektiğini, kutsal mekanın aynı zamanda mübarek bir mekan olduğu, kutsal mekanlarda başka yerlerde yapılma imkanı olmayan ibadetlerin icra edildiği gibi niteliklere sahip olduğu sonucuna varabiliriz. ${ }^{48} \mathrm{Bu}$ bağlamda Kur'an'da İsrailoğullarına hitaben "Ey Kavmim! Allah'ın size (vatan olarak) yazdığı mukaddes yere girin ve arkanızı dönmeyin, yoksa kaybedenlerden olursunuz"49 denilmesi, yine "Musa! Ben, Senin Rabbinim! Öyleyse artık pabuçlarını çıkar ve bil ki, sen kutsal vadi Tuvâ'dasın!"50 gibi âyetler kutsal mekan kavramına işaret etmektedir. Kur'an'da bu şekilde kutsalın ifşasını gösteren pek çok yer ismine rastlamak mümkündür. Bunlar arasında özellikle Kâbe ile ilgili Kur'an'da yer alan ifadeler, ${ }^{51}$ Kâbe'nin Müslümanlar için en önemli kutsal mekan ve kutsal merkez olduğunu ortaya koymaktadır. 52 Kâbe'nin kutsallığını vurgulayan bir başka husus ise, namaz ibadetinde Müslümanların ona doğru yönelmesinin istenmesi ${ }^{53}$ ve hac ibadetinin onun etrafında gerçekleştirilmesinde yatmaktadır. ${ }^{54}$ Bunlar mümin için varoluşsal bir özellik taşıdıkları gibi, aynı zamanda, kutsalı tecelli ettiren semboller olarak da işlev görmektedir. ${ }^{55}$ Çünkü Kâbe, kendisini oluşturan somut unsurların ötesinde asskın ve kutsal olanı yansitmaktadir.

\footnotetext{
48 Kamil Güneş, İslam Düşüncesinde Kutsallı, İnsan Yayınları, İstanbul, 2010, s. $136-137$

49 Mâide 5/21

50 Tâhâ $20 / 12$

51 Mâide 5/95, 97; İsra $17 / 1$

52 Âli İmran 3/96; Bakara 2/ 125

53 Bakara 2/144, bkz. Kurtubî, Câmiu'l-Ahkâmi'l-Kur'ân, cilt 2, s. 159-160

54 Âli İmran 3/97, bkz. Mâturidi, Te'vilâtu'l-Kur'ân, cilt 2, s.362-372

55 Ömer Faruk Yavuz, "Kuran'da Kutsal Mekan, Zaman ve Eşya Kavramlarinın Sembolik Değeri", Cumhuriyet Üniversitesi İlahiyat Fakültesi Dergisi, say1$\mathrm{X} / 2,2006$, s. 393
} 
Kâbe, Müslümanların namaz kılarken yöneldikleri tek merkezi noktadır. Kâbe'nin kıble olarak seçilmesindeki maksat, sadece Kâbe'ye bakıp namaz kılmak değil, aynı zamanda Müslümanların namaz kılarken tek yöne bakmalarını sağlamak ve böylece namaz ibadetinde yön birliğini sağlamakta yatmaktadır. Eğer Kâbe'ye, tek merkeze bakıp namaz kılınması emredilmeseydi 56 insanoğlu kendisine göre kutsal ve muhterem saydığı yöne bakıp namaz kılar, belli bir zaman sonra muhterem ve kutsal saylan mekanlar bir nevi ibadet merkezi yerine gelebilirdi ki, bu durum İslam'ın hedeflediği tevhid inancına aykırı bir durum oluştururdu. İslam dini, ibadette ve ibadet şeklinde tefrikaların önüne geçmek, İslam dininin çokmerkezli ve çok yönlü olmasını ortadan kaldırmak için maddi durumu müsait olan Müslümanlara haccı farz kılmış, ${ }^{57}$ dolayısıyla Kâbe'nin merkezi kutsallığına işaret etmiştir.

Mekke $^{58}$ ve Medine'nin kutsal oluşu ya da geleneksel deyim ile "kutsal topraklar" denmesinin sebebi de insanların o topraklara bir nevi ayrı bir üstün vasıf yüklediğinin işaretidir. 59

Makalemizde özellikle üzerinde durmak istediğimiz konu kutsal ve kutsallaştırılmış mekanın itikattaki yeridir. Çünkü bazı bölgelerde türbelere gizli bir ilahi güç atfedilmekte, orada olağanüstü manevi üstünlüğün var olduğu şeklinde bir inanç oluşmaktadır. ${ }^{60}$

56 Bakara 2/144; Enfal 8/34; Tevbe 9/7

57 Âli İmran 3/97

58 Mekke'nin adı Kur'an'da Bekke ve Ümmü'1 Kura (şehirlerin anas1) şeklinde geçmektedir. "Ey Muhammed! Böylece şehirlerin anası olan Mekke'de ve çevresinde bulunanları uyarman ve hakkında hiç şüphe olmayan kıyamet ile onları korkutasın" Şura 42/7; ayrıca bkz. Fetih 48/24; Âli İmran 3/96; En'am 6/92; Tevbe 9/40; Ankebut 29/67. Kur'an'ın iki âyetinde Mekke üzerine yemin edilmektedir, bkz. Tîn 95/1-3; Beled 90/1

59 Ahmet Güç, "Kuran'da Kutsallık Anlayışı", s. 250

60 Aslında kutsal mekan sayılan türbelerin ziyaretleri ile Türklerin eski ve köklü inançlarından biri olan "atalar kültü" arasında bir bağ bulunmaktadır. Nitekim eski Türkler ata ruhlarına büyük sayg1, hürmet ve tazim göstermekte ve dar zamanlarda ata ruhlarının kendilerine yardım ettiğine, ata ruhlarının onları desteklediklerine inanmaktaydılar. Bkz. Yusuf Ziya Yörükan, Müslü- 
İslam âleminin tamamına yakınında bulunan ve bir nevi medet kapısı, ümit eşiği addedilen türbelerin İslam inancına aykırı olup olmadığı konusunda genellikle, türbelerin zararsız, olmasında bir beis yoktur, diyenler; ${ }^{61}$ zararl1, uzun vadede itikadi sorunlara sebep olabileceğini söyleyenler ve her türlü kutsallaştırılmış mekanı İslam itikadına aykırı bulup derhal bertaraf edilmesini savunanlar, şeklinde üç görüş yaygındır. Çeşitli faydalar umularak ziyaret edilen türbe, ağaç, bölge ve mağaraların ziyaret edilme sebep ve amaçlar1na bakıldığında genellikle, ya mânevi maksat ya da maddi menfaat olmak üzere iki amaçla ziyaret edildiğini görüyoruz.

Türbe ve kutsal mekan ziyaretine gidenler genellikle amaçlarının maddi bir menfaat olmadığını, orada sadece dua etmek, manevi bir haz ve feyiz almak için geldiklerini ifade etseler de, birçok bölgede türbeleri veya kutsal mekanları ziyaret edenlerin hastalıklardan şifa bulmak, çocuk sahibi olmak, yağmur duası için orada bulunmak, dilek tutmak ve adak adamak, kısmetinin açılmasını ümit etmek, mal mülk sahibi olmak, her türlü beladan korunmak için gittikleri de bir hakikattir. ${ }^{62}$ Görünen o ki, türbe ve kutsal mekanların ziyaretindeki amaç, buraların bir medet kapısı olarak görüldüğüdür.

Allah'in dişında herhangi bir kimseden dilekte bulunmak tevhid dinine aykır163 olmasına karşın, bu durum gerçek tevhid bilgisinden yoksun insanları tatmin edebilmektedir. ${ }^{64}$ Öte yandan kutsal mekanlarda gerçekleştirilen ziyaretlerin ticari yönden bir payının olduğu da unutulmamalıdır. Sağlık, zenginlik, sinavda veya ticarette başarı garantisi, kısmet vs. gibi umutların "dağıtıldığı" veya o duygulara ulaşıldığı yer olan birçok türbenin şöhreti, onun esrarlı kud-

manlıktan evvel Türk Dinleri Şamanizm: Şamanizm'in Diğer Dinler ve Aleviler Üzerinde Etkileri, Yol Yayınları, Ankara, 2005, s. 32

${ }^{61}$ Bkz. Kamil Güneş, İslam Düşüncesinde Kutsallı, s. 190-193

62 Daha geniş bilgi için bkz. İskender Oymak, "Akçadağ ve Çevresinde Kutsal Mekan Anlayışı", Fırat Üniversitesi İlahiyat Fakültesi Dergisi, Sayı 5, Elazığ, 2000 , s. $462-464$

63 Müzemmil 73/8

64 İbn Teymiyye, İbn Teymiyye Külliyatı (Mecmuu'l-Feteva), 1.cilt, Tevhid Yayınlar1, İstanbul, 1986, s. 270-271 
retinden daha çok insanların konuştukları uydurma bilgilerden ibaret olabilme ihtimali yüksektir.

İslam dünyasının birçok yerinde insanların türbelerde tapınma derecesine varabilen bağlılıkları, aynı cahiliye dönemi insanlarının putlara ve kahinlere tapınmalarına benzemektedir. ${ }^{65}$ Müslümanların hastalığın tedavisi için bir türbeye adak sunmaları, çocuğu olmayanların, kısmeti açılmayan gençlerin, sınav öncesi ve önemli dönüm noktaları öncesinde Allah'a dua etmek yerine türbelere gitmeleri, birçok zaman orada sabahlamaları, kuyruğa girmeleri, şah damarından daha yakın olan ${ }^{66}$ Allah'ı terk edip, Allah'a yakın olmak için tekrardan aracı ve tevessül aramasının İslam dini açısından doğru olmadığını düşünmekteyiz.

Türkiye'de kutsal mekan sayılan türbelerin dışında bazı önemli "Dede"lerin mezarları ve manevi güçleri insanlar arasında ilgi görmektedir. ${ }^{67}$ Örneğin, "Türkmen Alevi"leri Evci Tahtacı Dede ziyaretine önem vermekte, dedenin mezar ziyareti genelde Perşembe günü yerine getirilmektedir. Ziyaretin nedeni ne olursa olsun mutlaka kurbanlık koç veya horoz adağı yapılmakta, adakların dedenin mezarı başında kesilmesi gerekmektedir. Hatta dedenin mezarlığının bulunduğu dağın sahibi olduğu zannedilmekte, mezarlığın önüne gelen herkes ayakkabısını ve çorabını çıkarıp mezarı başındaki taşa "Ya Allah! Ya Muhammed! Ya Ali!" diyerek niyazda bulunmaktadır. Eğilerek dedenin mezar başına giden ziyaretçi, üç kere secde etmekte, üçüncü secdede ise, 'Dedem, bana çocuk ver, bana sağlik ver, bana rızkımı ver, yağmur ver' vs. şeklinde, istek ve talepleri iletmek-

${ }^{65}$ Bkz. M.Şemseddin Günaltay, "Ölüleri Kutsallaştırma: Türbeler ve Ziyaret Yerle$r i$, sadeleştiren: Ahmet Gökbel, Cumhuriyet Üniversitesi İlahiyat Fakültesi Dergisi, say1 1, Sivas, 1996, s.189

66 Kâf 50/16

67 Bkz. İskender Oymak, "Akçadağ ve Çevresinde Kutsal Mekan Anlayışı", Firat Üniversitesi İlahiyat Fakültesi Dergisi, sayı 5, Elazığ, 2000; Bayram Erdemci, Eruh ve Pervari Yöresinde Kutsal Mekan Anlayışı ve Yaygin Halk İnançlar, (basılmamış yüksek lisans tezi), Van, 2010 
te, dilekte bulunmaktadır, ${ }^{68}$ ve maalesef bu ziyareti yapan da Allah'ın tek olduğuna, İslam'ın tevhid dini olduğuna iman eden Müslümanlar olmaktadır.

\section{c. Kutsal Zamanlar69}

Kutsal olan diğer bir fenomen ise kutsal zamanlardır. Bazı zamanların kutsallık açısından ön plana çıktığı ve diğer normal zamanlardan ayrıldığı görülmektedir. Kutsal zamanı normal zamanlardan ayıran en önemli özelliğin "şimdi" haline dönüştürülmüş olması, yani kutsal zamanların ilk yaşandığı gibi şimdide yaşanabilir bir özelliğe sahip olmasında yatmaktadır. ${ }^{70}$ Kutsal zaman kutsal olmayan zamandan, sergilediği dinamik ve yoğun anlamlar içerisinde farklılaşır. Bu farklılıklar onu sıradan bir zaman dilimi olmaktan çıkarır.

Kuran'da kutsal zamana örnek olarak kadir gecesi ${ }^{71}$, ramazan ay1 $^{72}$, hac aylar1 ${ }^{73}$ gibi zamanlara işaret edilmektedir. Dolayısıyla bazı aylar, ${ }^{74}$ bazı günler, ${ }^{75}$ bazı geceler ${ }^{76}$ gibi zaman dilimleri Kutsal'ın tecellisi olma nedeniyle diğer zaman dilimlerinden ayrılmaktadir.

68 Dede mezarları ziyaretiyle ilgili geniş bilgi için bkz. Ali Selçuk, "Dede Mezarındaki Str: Ziyaret Fenomeni ve Kutsalın Tezahürleri", Türk Kültürü ve Hacı Bektaş Veli Araştırma Dergisi, sayı 56, 2010, s. 65-66

69 Sembol-kendisinin ötesinde olan bir gerçekliği işaret eder. Sembol, işaret ettiği ya da yansıttığı şeye katılmaktadır. Sembollerin ya bilinçaltında oluşmas1 ya da Kur'an gibi yüksek bir otorite tarafından empoze edilerek kabul görmesi gerekir. Bkz. Ömer Faruk Yavuz, "Kuran'da Kutsal Mekan, Zaman ve Eşya Kavramlarının Sembolik Değeri", s. 387-388

70 Ömer Faruk Yavuz, "Kuran'da Kutsal Mekan, Zaman ve Eşya Kavramlarinın Sembolik Değeri", s. 398

${ }^{71}$ Kadir 97/1-5

72 Bakara 2/185

73 Bakara 2/197

74 Bakara 2/185; Tevbe 9/36

75 Cuma 62/9

76 Kadir 97/ 1-5 
Yine İslam dünyasında kutsal olduğunda ittifak edilen Mirac, Regaib gibi kandil adı verilen mübarek gecelerde dua ve ibadetler edilmekte, toplumsal birliktelik meydana gelmektedir. Şîa mezhebinde ise Hz. Ali'nin doğum günü77, Hz. Muhammed'in Ali'yi halife seçtiğine inanılan gün ${ }^{78}$ ve tarihi Kerbela olayının yaşandığ $10 \mathrm{Mu}-$ harrem günü son derece önem arzetmektedir.

Ramazan ayı; Kuran'ın indiği günü içerisinde barındırması, oruç ibadetiyle kulların Allah'a yakınlıklarının artmas1, Resulullah'ın Ramazan ayının dışında Muharrem ayında oruç tutmanın önemine dikkat çekmesi, Cuma günü bütün Müslümanların bir araya gelip Allah'1 anmaları, ${ }^{79}$ namaz vakitleri, kulun Allah'a en yakın olduğu anları içerisinde barındırması; Kadir gecesi, ki tan yerinin ağarmasına kadar meleklerin inmesi ve rahmet kapılarının sonuna kadar açılması gibi Kutsal'ın tezahür ettiği zaman dilimleri olmaları nedeniyle kutsallığa bürünmekte ve diğer zaman dilimlerinden ayrılmaktadırlar. Burada söylenmesi gereken önemli bir husus, Kadir gecesinin hangi güne tekabül ettiğinin hem Allah hem Hz.Muhammed tarafından bildirilmemiş olması bile aslında o günün aşırı kutsallaştırılmasını önlemekten ibaret olduğunu ortaya koymaktadır. Dolayısıyla İslam dininde zamanın kutsallaştırılması yönünde de birçok önlemin olduğu kanaatindeyiz.

Öte yandan Kur'an'da zaman mefhumuna edilen yemin, zamanın kutsal olmasında değil, her geçen zamanın önemli olduğuna, kaybedilen zamanın insanoğlu için bir hüsran olduğuna ${ }^{80}$ dikkat çekmek içindir. Çünkü İslam'dan başka hiçbir din, hiçbir inanç, hiçbir felsefi ve iktisadi sistem kendi mensuplarından bir saniyenin hesabını bu kadar ciddiyetle sormaz ve bir saniyelik ihmali bu kadar ağır bir şekilde eleştirmez. Affı ve cömertliği sonsuz olan Allah'ın

\footnotetext{
77 Recep ayının 13. günü

78 Zilhicce ayının 18. günü

79 Cuma 62/9

80 Asr 103/1-3
} 
Kuran'da zaman faktörüne yemin etmesi, ${ }^{81}$ dünyada zaman kavramının daha kuvvetli belirginleşmesi amacını taşımaktadır. ${ }^{82}$

\section{d. Kutsal Değerler}

Kutsal kimlik, mekan ve zamanın dişında bir de kutsal görülen, mensuplarınca sevilmesi şart koşulan birçok kutsal değer İslam dünyasında yaygınlaşmış durumdadır. Mensuplarınca kutsallaştırılan değerlere olan bağl1lık, o değerleri sevmeyen, beğenmeyen kimselere karşı düşmanlığı, kini doğurmaktadır. Düşmanlık ve kin zamanla mezhep, görüş, fikir taassubuna itmekte, en sonunda da görüş mensupları arasında fikri ve fiziki çatışmalar meydana gelmektedir. Halbuki kutsal olanın ancak Allah olduğu kabul edilirse, diğer yandan da insana ait olan her şeyin insanların görüşünden ibaret olduğu savı doğru anlaşılırsa, tahminimizce Müslümanlar arasında bugünkü kadar tefrikalar meydana gelmezdi.

Kutsal değerlerin saygınlığı ve dokunulmazlığına örnek olarak Şîa mezhebinin Ehl-i Beyt'i ve Hz. Ali'ye olan sevgisi gösterilebilir. Şîa inancina göre $\mathrm{Hz}$. Ali ve onun soyundan gelen on bir imam, $\mathrm{Hz}$. Adem'den itibaren bütün peygamberlere verilen ilme ve sifatlara sahiptirler, imamlara itaat etmek demek peygambere itaat etmekle eşdeğerdir. Onları sevmek bir nevi ibadettir. Çünkü dünya ve ahiret onlar için yaratılmıştır. ${ }^{83} \mathrm{Bu}$ şekildeki görüş, yaklaşım ve inanç Ehli Beyt'i kutsallaştırma çabasından başka bir şey olmayıp, bu durumun tevhid ilkesini ihlal edecek boyutlara ulaştığını görebilmekteyiz. Halbuki Allah Kur'an'da ilk peygamberin dahi beşeri yönünü ön

${ }^{81}$ Asr 103/1; Duha 93/1-2; Tekvir 81/15-18; İnşikak 84/16-18; Fecr 89/1-5; Leyl 92/1-4 vd.

82 Bkz. Emannullah Polat, "Kutsalın Psikolojik Boyutu", Bingöl Üniversitesi İlahiyat Fakültesi Dergisi, sayı 3, 2014, s. 41

83 Geniş bilgi için bkz. Şeyh Sâduk Ebû Câfer Muhammed b. Ali İbn Bâbeveyh el-Kummî, Risaletu'l-İ'tikâdati'l-Imamiyye, Çev., E.Ruhi Fığlalı, Ankara, 1978, s.104; Muhammed Hüseyin Kâşifu'l-Gıta, Şîa Nedir, Çev., Abdullah Ünlü, İstanbul, 1996, s.32; Şahin Ahmetoğlu, "İslam Mezhepleri Tarihinde Karizmatik Liderlik Anlayışı: Hz. Ali örneği", Milel ve Nihal: inanç, kültür ve mitoloji araştırmaları dergisi, cilt 7, sayı 3, Eylul-Aralık 2010. 
planda tutmuş, Hz. Muhammed ise tüm öğretilerinde tevhid ilkesi konusunda titizlik göstermiştir.

Allah'ın dişında herhangi bir varlı̆̆ın, değerin, kimsenin kutsallaştırılması, akabinde putlaştırılması, kabulü mümkün olmayan ve İslam itikadı açısından tehlike arzeden bir yanılgı olmaktadır. ${ }^{84}$

\section{KUTSAL -ŞİRK SINIRI}

İnsanın fitratında bozulmaya, ihlale, tecavüze, eksikliğe, noksanlığa maruz kalmayan bir kutsala karşı, güçlü bir değere olan sürekli yöneliş, ona doğru bir eğilim ve ilgi her zaman söz konusudur.

Allah insanların yaratılışındaki en önemli sebebi Zâriyat süresinde: "Ben cinleri ve insanları ancak bana ibadet etsinler diye yarattım" 85 şeklinde açıklamış, "...O size, kendisinden başkasına ibadet etmemenizi emretmiştir"86 âyetinden hareketle insanların yaratılış gayesinin öncelikle Allah'ı tanımak ve O'na ibadet etmekten ibaret olduğunu ifade etmiştir. Bu sebepten dolayı İslam'a ve tek Allah'a inanmak, en mükemmel şekilde itaat etmeyi gerektirir. ${ }^{87}$

Allah'1 bırakıp O'ndan başkasından medet ummak, sadece Allah'tan beklemesi gerekenleri fâni olandan istemek, makul saygi sınırlarını geçip yaratılan insana ${ }^{88}$ yakışmayacak şekilde değerler önünde eğilmek tevhid dini olan İslam'a aykırı bir durum teşkil etmektedir. Kuran'da zikredilen "Allah'tan başka kendilerine dua edip taptığınız neler varsa, hepsi bir araya gelseler bir sineği bile yaratamazlar"89 âyeti Allah'tan başkasına dua ve ibadet etmenin hiçbir

\footnotetext{
84 Seyyid Ebü'l-A'la Mevdudi, Tefhimu'l-Kuran,trc. Muhammed Han Kayani, cilt 1, İnsan Yayınları, İstanbul, 1986, s.589; Hüseyin Yunus, Tekfir Meselesi, Ahenk Yayınları, Van, t.y., s. 59

85 Zâriyat 51/56

86 Yusuf $12 / 40$

87 İbn Teymiyye, İsim ve Sıfat Teuhidi, Tevhid Yayınları, İstanbul, t.y, s. 104

88 Tîn $95 / 4$

${ }^{89}$ Hac $22 / 73$
} 
işe yaramayacağına, çünkü Allah'ın dışındaki her şeyin ve her varl1ğın ancak bir mahlukat olduğuna işaret etmektedir.

Kutsal konusunda Allah'ın Kur'an'da mukaddes olarak vasiflandırdığı mekanlar ve varlıklar vardır. Ama kanaatimizce, Kuran'da zikredilen "kutsal" çağrışımı "saygı, ihtiram gösterilmesi gereken" anlamını içermektedir. Kur'anî perspektife göre peygamberler de dahil olmak üzere şehitler, salihler, veliler ve âlimlere kutsiyet atfedilemez. ${ }^{90}$

Kutsal ve kutsallaştırma konusunda en doğru yolu bize Kur'an göstermekte, tarihi verileri ve Allah'ın sıfatlarını tanıtmaktadır. Fakat, Kur'an'ın herkes tarafından okunmak ve anlaşılmak üzere indirildiği gerçeğine rağmen yine de İslam geleneğinin kimi eğilimleri içinde Kur'an'ın belki aşırı bir saygı saikıyla dokunulmaz kılındığına, dokunulmazlık halesiyle insanlardan uzaklaştırılmış olduğuna şahit olmaktayız. Bu ssekilde Kur'an, hayata tatbik etmek yerine kutsanmış ve belli aralıklarla tazim edilen, hayata, iç dünyaya nüfuz edemeyen, vefat etmişlerin ruhuna okunan bir kitap konumuna yerleştirilmektedir. Bu tutum Kur'an'ın rehber olarak gönderiliş amacına uymayan zararları ve sonuçları vahim olan bir tutumdur.

Aynı şekilde Hz. Muhammed'in şiddetle karşı çıktığı, kendisinin getirdiği öğretilere kökten aykırı olan aşırı yüceltmeci tavır, itikadi açıdan tehlike arz eden bir tutumdur. Bu tavır O'nu efsaneleştirerek, getirdiği mesajların O'nun imajının gölgesinde kalması yani hayatın dışına atılması sonucunu doğurmaktadır. ${ }^{91} \mathrm{Bu}$ anlayışla

90 Nisa 4/ 69, 172

91 Kur'an'ın 1srarla tenkit ettiği hususlardan birisi, körü körüne taklit zihniyetidir. Örneğin Hz. Musa, Firavun kavmine gönderildiğinde şöyle karşıl1k verirler: "Bu ancak uydurma bir sihirdir. Biz önceki atalarımızdan böyle bir şey işitmedik"(Kasas 28/36). Hz. Nuh'un kavmi de benzeri ifadeleri kullanır (Müminun 23-24). Hz. Muhammed de aynı zihniyetle karşılaşmıştır. Kur'an bunu şöyle dile getirir: "Onlara, Allah'ın indirdiğine uyun" denildiğinde "hayır biz atalarımızın yoluna uyacağız" derler. Ya ataları bir şeye akıl erdiremiyor ve gerçek yolda değillerse?" (Bakara 2/170) diyerek ataların, geçmişin örf-adetinden daha çok Allah'ın emrine, Kur'an'ın emirlerine göre hareket etmeleri gerektiğini buyurmaktadır. 
Hz. Peygamber'e bakmak; O'nu örnek almayı imkansız kılmakta, yaşayan, canlı bir örnek olmaktan uzaklaştırmaktadır.

İslam'ın karakteristik özelliği şudur ki, bu dinde Allah kuluna tek başına kafi olup, ${ }^{92}$ O'nun yanında yardımcı kabul etmek, ona ulaşmakta birilerini araya sokmak zulüm sayılmakta ve en büyük günah olan şirke doğru sevkedebilmektedir. ${ }^{93}$ Hz.Muhammed'in peygamberlik fonksiyonlarının temel hedefi bütün şirk ve şirke giden unsurları yok etmek iken, Allah'a yakın olmak için aracılardan istifade etmek, aracılardan yardım dilemek de bir nevi şirke götüren vesile olabilmekte, ${ }^{94}$ hatta birçok durumda şirk kategorisine dahil olmaktadır, çünkü şirk Allah'a açıkça ortak koşmakla sınırlı olmayıp, şirk niteliği taşıyan ve şirki çağrıştıran çeşitli türleri de mevcuttur. ${ }^{95}$ Yüce Allah'a inanmakla birlikte O'na ulaşmakta yardımcı güçlere tapmak putperestliğin bir işaretidir. Çünkü putperestlik inancinda da putlar aracı olmakla birlikte putlara yapılan ibadetin yine nihayetinde Tanrı'ya gittiğine inanılmaktadır. ${ }^{96}$

92 Zümer 39/36

93 Bkz. "Allah'a ibadet edin ve hiçbir şeyi Allah'a ortak koşmayın" (Nisa 4/34); "Ondan basska ilah yoktur. Her şeyi yaratan O'dur. O halde yalnız O'na ibadet edin" (En'am 6/102); "Her kim Rabbine kavussmay1 dilerse, salih bir amel işlesin ve Rabbine yaptığı ibadette hiç kimseyi ortak koşmasın" (Kehf $18 / 110)$.

94 İbn Teymiyye, İbn Teymiyye Külliyatı (Mecmuu'l-Feteva), cilt 1, s. 392

95 1) Şirki istiklâl: Allah'ın dışında ilah olduğuna inanmaktır. Mecusilerin iyilik ve kötülük tanrısı inancı gibi; 2) SSirki Teb'îz: Allah'ın birden fazla ilahtan meydana geldiğine inanmaktır. Hıristiyanların teslis yani "baba-oğul-ruhu'l kudus" inanc1 gibi; 3) Şirki Takrib: Allah'ın bir olduğuna inanmakla birlikte O'na yaklaştırsın ve ona yaptığımız dualarımız kabul edilsin diye put, heykel, tapınak vs. şeylere inanmaktır; 4) Şirki Taklid-körü körüne ataların batıl dinine inanmaktır. Cahiliye dönemindeki Araplar bu inançlarla putlara taparlard1;5) Şirki esbab: kainatın Allah'ın yaratması ile değil de kendi kendine var olduğuna inanmaktır. Materyalist ve maddeciler bu inançtadır. Bkz. Ahmet Saim Kılavuz, İslam Akaidi ve Kelama Giriş, Ensar Neşriyat, İstanbul, 1997, s. 43

96 Putperestlik konusunda geniş bilgi için bkz. Cevad Ali, el-Mufassal fi Tarihi'tArab Kable'l-İslam, Dârü'1-İlm li'l-Melayin, cilt 6, Beyrut, 1978; Aynur Eryiğit Bader, Yahudilik Hıristiyanlık ve İslam'ın Putperestliğe Bakışı, (basılmamış doktora tezi), Ankara, 2008 
Nefsini put yapanlar ${ }^{97}$ diyerek insanoğlunu her zaman şirk ve nefis konusunda uyaran Allah'in özellikle bu âyetini görmezden gelip, tek kutsal olan, tek yüce varlık olan, her şeyin üzerinde yapt1rım gücü olan Allah'tan uzaklaşmak aslında teslim akdinden, teslim ve tevhid vefasından uzaklassmaktır.

Allah, "şahdamarından daha yakınım"98 tabiriyle insanoğluyla içiçe olduğunu açıkça belirtmiş iken, ayrıca Müslüman bir kimse İslam'ı kabul etmekle gönlünü, kalbini, inancını, düşüncesini ve varlığını Allah'a "teslim" etmişken, bu bağlantıyı, bu teslimiyeti, bu içiçe olmayı bırakıp kendi kendine şüpheye düşerek, Allah'a daha yakın olayım, dualarım bir "üstün!" şahsiyetin, değerin yüzü suyu hürmetine kabul edilsin, diyerek Allah ile olan akitten, bağdan uzaklaşılması tevhid ilkeleriyle çakışmaktadır. ${ }^{99}$ Namaz vasıtasıyla, tek bir kere anmak ile Allah'a ulaşmak, O'nunla muhatap olmak mümkün iken, Allah'ın işitme ve görme, her şeyi kuşatma sıfatlarını unutarak, görmezlikten gelerek yaratılmışların gücünden, onun Allah katındaki hürmetinden dolayı yardım beklemek, kanaatimizce tevhid inancinı zedelemektir.

\section{DEĞERLENDİRME}

Makalemizin özünü oluşturan kutsal ve kutsallaştırma, kutsallaştırma ile şirk arasındaki ince noktalar, İslam itikadı açısından son derece önemli bir yere sahiptir. Çünkü Kelam bilimi kalıp olarak zihinlere yerleşmiş olan ve tahkik etme ihtiyacı hissedilmeyen bazı itikatları/inançları sorgular, müminlerin zihninde asırlardır ezberlenmiş malumatların sürekli tekrarlanmasından dolayı bir kurtuluş ve çıkıs yolu bulmaya çalışmaktadır.

\footnotetext{
97 Furkan 25/43

98 Kâf 50/ 16

99 Bkz. İbn Teymiyye, İbn Teymiyye Külliyatı (Mecmuu'l-Feteva),cilt 1, s.313-314, 418
} 
İslam dini düşünmeyi, araştırmayı, çalışmayı ibadet sayarken, maalesef çeşitli dokunulmayan, sorgulanmayan değerler sayesinde aklı mahkum eden bir yapıya büründürüldü. Muhtemelen, İslam düşüncesindeki bazı itikat ve inançtaki sapmaların, aklın mahkum edilmesiyle beraber başladığı söylenebilir.

Kutsalın, dini hayatın vazgeçilmez bir temeli olduğu doğrudur. Fakat kutsama faaliyetinin niteliği, kutsallaştırma kadar önemlidir. Eğer kutsama faaliyeti bir kişiyi, bir mekanı, bir eşyayı, bir zamanı mutlak kutsal (Allah) ile irtibatlandirırken anlamlı, bilgi temelli, fonksiyonel, tartış1lır olmaktan çıkarıp anlamsız, sebepsiz, sırrî, gaybî, kapalı hale getiriyorsa bu kapalı kutsamadır, ${ }^{100}$ kapalı kutsallıktır. Çünkü "Kutsal" manevi sahada mükemmelliğin, tam ve yetkin olmanın dini terimidir. Manevi sahada mükemmellik ve yetkinlik, en üst ve son derecesini Allah'ta bulur. Bunun için en kutsal varlık Allah'tır. O, her türlü acizlik ve noksandan uzaktır. Bütün mükemmellikler ve yetkinlikler Allah'ta toplanır ve O'nun kutsall1ğın1 pekiştirir. ${ }^{101}$

Allah, peygamberler aracılığıyla ibadet edilmesi gereken tek ve yalnız kutsalın kendisi olduğunu bildirmesine rağmen, insanoğlu tarih boyunca itikat noktasında sürekli yoldan çıkmıştır. Zamanla, Allah'a ulaşmak maksadıyla vesileler aramaya başlamış, bunun neticesinde önce kainattaki varlıkların kudret sahibi olduğuna, sonra insanların, daha sonra ise hayvan, nesne, put, ahşaptan yapılma totemler vs. gibilerin büyük güç sahibi olduğuna inanmış, bu şekilde itikat etmiştir. Peygamberlerin gönderilmesindeki amaç ta zaten bu tür yanlışları önlemek, yanlış inançların önünü kapatmak, yanlışlardan dönülmesini sağlamaktan ibaret olmuştur. ${ }^{102}$ Bütün peygamberlerin görevi, korkulacak ve sevilecek tek kutsal varlığın Allah olduğunu, kainatın tek yaratıcısı ve düzenleyicisinin kendisinin olduğunu, Allah’tan başkasına ibadet edilmemesi gerektiğini, Al-

100 İlhami Güler, Sabit Din Dinamik Şeriat, s. 75

101 Ahmet Güç, "Kuran'da Kutsallık Anlayışı", s. 252

102 Muhammed Karaca, Kuran ve Sünnete Göre Tevhid ve Akaid, Ribat Yayınları, Konya, t.y., s. 44 
lah'ın dişında kutsal bir varlık edinildiğinde bunun şirke hatta küfre götürebileceğini duyurmaktan ibaret olmuştur. ${ }^{103}$

Kimliği ve niteliği ne olursa olsun hiçbir kutsallaştırılmış değer, yüce sıfatlarla aynileşemez. İslam coğrafyasının birçok bölgesinde kutsallaştırılmış öyle türbeler vardır ki türbe sahibinin hürmeti ve kıymeti Hz. Muhammed'in kat-kat üstüne çıkmış ve medet umulur bir varlığa dönüşmüştür. ${ }^{104}$

Eğer bir Müslüman Allah'ın dışında başka kutsallar ararsa, kutsal değerlere önem verirse, onun saygı duyduğu bir kutsal diğer kutsalı ötekileştirir. Bir Müslüman için kutsal kabul edilen değer, mekan, fikir, önder, mezhep veya görüş, ötekiler tarafından eleştirilirse ya da küçümsenirse birinci taraf için ikinci taraf dinden çıkmış sayılabilmektedir. Halbuki herhangi bir dine ait olan kutsalın değerleriyle alay etmek veya onlara hakaret etmek, kendisine ait olan kutsalla ilgili düşünceyi yaymak için tahrik etmek ve kışkırtmak, hatta birçok zaman şiddete başvurmak İslam diniyle bağdaşmaz ve İslam'ın insanlara tanıdığı ifade özgürlüğü kapsamında değerlendirilemez. ${ }^{105}$ Zira İslam, bir Müslümanın başka bir dinin kutsal değerlerini tahkir düzeyinde yermesini ve o dinin söz konusu değerlerini hafife almasını yasaklamıştır. ${ }^{106}$

Tevhid inancin1 $1^{107}$ ön planda tutan Kur'an 108 insana şahdamarından daha yakın olan Allah'a ibadet etmeyi emretti. ${ }^{109}$ Böylece

103 Peygamberlerin tevhid uğrunda verdikleri mücaleler konusunda geniș bilgi için bkz. İsmail Çakan-Mehmet Solmaz, Kuran-ı Kerim'e Göre Peygamberler ve Tevhid Mücadelesi, Ensar yayınları, İstanbul, 2014.

104 Bkz. İbn Teymiyye, Mecmuatur-Resaili'l-Kübra, cilt 1, Misır, hicri 1323, s. 309; ayrıca bkz. Ahmet Saim Kılavuz, İman-Küfür Sinırı, Marifet Yayınları, İstanbul, 1990, s. 144

105 Bkz. Ali Aslan Topçuoğlu, "Kur'an ve Sünnete Göre Iffade Özgürlüğü ve Kutsal Değerlere Saygı", İslam Hukuku Araştırmaları Dergisi, sayı 7, Nisan 2006, s. 121

106 En'am 6/108; Hucurat 49/11, bkz. Kurtubî, Câmiu'l-Ahkâmi'l-Kur'ân, cilt 7, s.61; Mâturidi, Te'vilâtu'l-Kur'ân, cilt 14, s. 71-75

107 İslam inancında en yüce varlık Allah'tır. Bundan dolayı İslam itikadında Allah fikri her şeye hakimdir ve bütün anahtar terimlerin semantik yapısı üzerinde derin etkisini gösterir. Kur'an'da Allah kendisinin tek olduğunu (Âli 
insanoğlunun kalbinin ve aklının içinde olan Allah'a110 iman etmiş Müslümanın kutsal saydığı, kutsallaştırdığı mekanlarda dua etmesi, oralardan medet umması İslam inancına aykırı bir durum teşkil etmektedir. Kutsal mekanlara, türbelere dua etmeye giden Müslümanları putpereste benzetmek, bu tür eylemler için biraz kaba ve yakışıksız olsa da bütün putperestliğe giden yollar, ilk aşamada aynı silsileden geçmiştir. Buna göre şahıslara, mekanlara, değerlere önce bir hayranlık uyanmış, sonrasında o, Tanrı ile insan arasında bir referans olduğuna inandırılmış, daha sonraki devirlerde nesiller tarafından yanlış yorum ve anlatımlarla sözkonusu varlıklar kutsallaştırılmıştır. Kur'an bazı toplum ve kişilerin melekleri ve peygamberleri ilahlaştırdıklarını haber vermekte, bu eylemi putperestlik kategorisine dahil etmektedir. ${ }^{111}$ Namazın her rekatında "Ancak sana ibadet eder ve ancak senden yardım dileriz"112 diyen Müslümanın duasının kabul edilmesi için Allah ile insan arasına başkalarını tevessül etmek, hedef şaşırtmaktır.

Günümüzde kutsallaştırılmış türbelere, mezarlara, özel mekanlara giden insanların çoğu "Bunlar duamızın Allah'a ulaştırılması için bir vesiledir, bunların yüzü suyu hürmetine kabul olması için dua etmeye geldik" demeleri tıpkı cahiliye dönemi Araplarının, "Putlar bizim isteklerimizi ve dualarımızı Allah'a ulaştıran vesilelerdir" 113 demelerinden hiçbir farkı yoktur ve itikadi anlamda yanlıştır, bir

İmran 3/2, Enbiya 21/22,23) ve dolayısıyla tek kutsal varlık olduğunu zikreder.

108 "Bu Kuran, kendisiyle uyarılsınlar, Allah'ın ancak tek ilah olduğunu bilsinler ve akıl sahipleri düşünüp öğüt alsınlar diye insanlara bir bildiridir" (İbrahim 14/52), "Sakın Allah'a ortak koşanlardan olma, Allah'ı bırakıp da sana ne fayda ne de zarar verebilecek olan şeylere yalvarma. Eğer böyle yaparsan şüphesiz sen zalimlerden olursun"(Yunus 10/105-106)

109 Ankebut 29/45; Bakara 2/238; Tevbe 9/5; Cuma 62/10; İsra 17/79; Bakara 2/43, 45, 110, 153, $277 \mathrm{vd}$.

110 Bkz. İbn Teymiyye, Kulun Allah'a Yaklaşması, Tevhid Yayınları, İstanbul, 1996, s. 25-29

111 Bkz. Âli İmran 3/80; Mâide 5/73,75,116; Nisa 4/171; Tevbe 9/31

112 Fatiha $1 / 5$

113 Zümer 39/3 
nevi putperestlerin ilk başladığı adımları atmış olmakta114 ve Kur'an'daki tevhid mesajını açık ihlal etmektedir.

Hz. Muhammed'e bile Allah'ın vekili olma keyfiyeti verilmediği ${ }^{115}$ âyetlerden açıkça anlaşılmaktadır. Bundan hareketle tebliğ ve uyarıdan ${ }^{116}$ basska görevi olmayan peygamberlerin ve muhterem zatların mezarlarının dualar için aracı edildiğinde hiçbir fayda etmeyeceği kanaatindeyiz. Âlimlerin, raşitlerin, velilerin, Allah yolunda ilim ve bilim cihadı yapanların, Allah yolunda ömür harcayanların, Allah yolunda mallarıyla, canlarıyla savaşanların, yüksek mertebelere ulaşmıs mutasavvıf zatların ancak biliminden, eserlerinden istifade etmek, onların ahlakını örnek almak esas iken onların manevi kuvvetlerinden medet ummak, duaların kabulü için aracı kılmak tevhid inancına aykırı bir durum oluşturmaktadır. Çünkü İtikadi açıdan bir insanı ikinci insandan üstün görmek, üstün olan insanı kutsallaștırmaya götürür.

Sonuç olarak, iman fiilinin fâili insandır, muhatabı ise insan aklıdır. Akıl tarafından kontrol edilmeyen iman istikameti bulamayabilir. ${ }^{117}$ İşte bu yüzden Kur'an, sorumluluğunu bilen insanlardan oluşan bir toplum modeli öngörmüştür. Allah'ın emirlerinden başkasını delilsiz ve itirazsız kabul etmek, Müslümanların düşüncelerinde, iradelerinde ve inançlarında çürümeye doğru bir işaret sayılır.

\footnotetext{
114 Cahiliye dönemi dini inanç ve uygulamalar hakkında geniş bilgi için bkz. Ali Osman Ateş, İslam'a Göre Cahiliye ve Ehli Kitab Örf ve Adetleri, Beyan Yayınları, İstanbul, 2014

115 Bkz. Şura 42/6; Kâf 50/45; Gașiye 88/21,22; Karşılaştırınız: Teğâbun 64/12, Şura 42/48; Yasin 36/17; Ankebut 29/18; Nur 24/54

116 Bkz. Mâide 5/67, 92,99; A'raf 7/62,68,79,93; Hûd 11/57; Ra'd 16/35,36,82; Ankebût 29/18; Ahzâb 33/39; Yâsin 36/17; Şûra 42/48; Ahkaf 46/23,35; Teğabun 64/12; Cin 72/23, 28

117 Mâturidi, Kitâbu't-Tevhid, s.607
} 


\section{KAYNAKÇA}

AÇIKGENÇ, Alparslan, "Kutsal, Gelenek ve Çağdaşlık", Eskiyeni Dergisi, sayı 17, İlkbahar 2010

AHMETOĞLU, Şahin, "İslam Mezhepleri Tarihinde Karizmatik Liderlik Anlayışı: Hz. Ali örneği", Milel ve Nihal: inanç, kültür ve mitoloji araştırmaları dergisi, cilt 7, sayı 3, Eylul-Aralık 2010

AN-NAYM, Arapça-Özbekçe İzahlı Büyük Lügat, Abdulla Kadiri Neşriyat1, Taşkent, 2003

ATEŞ, Ali Osman, İslam'a Göre Cahiliye ve Ehli Kitab Örf ve Adetleri, Beyan Yayınları, İstanbul, 2014

BADER, Aynur Eryiğit, Yahudilik Hiristiyanlık ve İslam'ın Putperestliğe Bakışı, (basılmamış doktora tezi), Ankara, 2008

CEVAD, Ali, el-Mufassal fi Tarihi'l-Arab Kable'l-İslam, Dârü'1-İlm li'1Melayin, cilt 6, Beyrut, 1978

COX, James L., Kutsalı Ífade Etmek, çev. Fuat Aydın, İz Yayıncılık, İstanbul, 2004

ÇAKAN, İsmail-SOLMAZ, Mehmet, Kuran-ı Kerim'e Göre Peygamberler ve Tevhid Mücadelesi, Ensar yayınları, İstanbul, 2014

ÇEVİK, Mustafa, "Kutsal'in Anlam Alanı", Yüzüncü Yıl Üniversitesi Sosyal Bilimler Enstitüsü Dergisi, sayı 13 /Bahar, Van, 2007

DEMİRCI, Kürşat,"Kutsiyet" maddesi, TDV İslam Ansiklopedisi, TDV Yayınları, cilt 26, 2002

ELİADA, Mircea, Kutsal ve Dindışı, çev. Mehmet Ali Kılıçbay, Gece Yayınları, Ankara, 1991

ELİK, Hasan, Dini Özünden Okumak, Kaleseramik Yayınları, İstanbul, 2004

ERDEMCI, Bayram, Eruh ve Pervari Yöresinde Kutsal Mekan Anlayışı ve Yaygin Halk İnançlar, (basılmamıs yüksek lisans tezi), Van, 2010 
ERKOÇOĞLU, Fatih, "Kutsallaştırılmış Bir Mekan: Kerbela", Çeşitli Yönleriyle Kerbela Sempozyum Sunumları, I.cilt, Kültür ve Turizm Yayınları, Sivas, 2010

EROĞLAN, Fatih, Fenomenolojik Açıdan Kutsalın Anlamı ve Toplumsal İşlevi, (basılmamış yüksek lisans tezi), Samsun, 2004

FİRUZABADİ, Muhammed b. Yakub Şirazi, Kamusu'l-Muhîd, cilt 2, Misir, 1330

GAZZALI, Ebu Hamid Muhammed b. Muhammed, el-Maksadu'tesna fi şerhi Esmâilillahi'l-Husna, Matbaatus Sabah, Şam, 1999

GÜÇ, Ahmet, "Kuran'da Kutsallık Anlayışı", Uludağ Üniversitesi İlahiyat Fakültesi Dergisi, sayı 9, Cilt 9, 2000

GÜLEN, Ömer, "Tanrı Kavramının-Kutsallaşması", Eskiyeni Dergisi, sayı 31, 2015-Güz

GÜLER, İlhami, Sabit Din Dinamik Şeriat, Ankara Okulu Yayınları, 3. Bask1, Ankara, 2012

GÜNALTAY, M.Şemseddin, "Ölüleri Kutsallaştırma: Türbeler ve Ziyaret Yerleri", sad. Ahmet Gökbel, Cumhuriyet Üniversitesi İlahiyat Fakültesi Dergisi, say1 1, Sivas, 1996

GÜNEŞ, Hüseyin, "Kutsal Değerlerin Siyasete Alet Edilmesi Bağlaminda Abdullah b. Ali İsyanı", Hitit Üniversitesi İlahiyat Fakültesi Dergisi, cilt 11, say1 22, 2/2012

GÜNEŞ, Kamil, İslam Düşüncesinde Kutsallık, İnsan Yayınları, İstanbul, 2010

HARAL, Günay, "İslam'da Kutsiyet" maddesi, TDV İslam Ansiklopedisi, TDV Yayınları, cilt 26, 2002

İBN MANZUR, Ebul-Fadl Cemaluddin Muhammed b. Murekkem, Lisanu'l-Arab, cilt VI, Beyrut, 1863

İBN TEYMIYYE, İbn Teymiyye Külliyatı (Mecmuu'1-Feteva), 1.cilt, Tevhid Yayınları, İstanbul, 1986 
İBN TEYMIYYE, İsim ve Sifat Tevhidi, Tevhid Yayınları, İstanbul, t.y.

İBN TEYMIYYE, Kulun Allah'a Yaklaşması, Tevhid Yayınları, İstanbul, 1996

İBN TEYMIYYE, Mecmuatur-Resaili'l-Kübra, cilt 1, Mısır, hicri 1323

KARACA, Muhammed, Kuran ve Sünnete Göre Tevhid ve Akaid, Ribat Yayınları, Konya, t.y.

KÂŞİFU'L-GITA, Muhammed Hüseyin, Şîa Nedir, Çev., Abdullah Ünlü, İstanbul, 1996

KILAVUZ, Ahmet Saim, İman-Küfür Sinır, Marifet Yayınları, İstanbul, 1990

KILAVUZ, Ahmet Saim, İslam Akaidi ve Kelama Giriş, Ensar Neşriyat, İstanbul, 1997

KIYAK, Abdulkadir, "Halk Dindarlığı Bağlamında Kutsal Mekan Anlayışı", Gümüşhane Üniversitesi İlahiyat Fakültesi Dergisi, cilt 1 , say1 2, 2/2012

KUMMÎ, Şeyh Sâduk Ebû Câfer Muhammed b. Ali İbn Bâbeveyh, Risaletu'l-I'tikâdati'l-İmamiyye, Çev., E.Ruhi Fığlalı, Ankara, 1978

KURTUBÎ, Ebî Abdullah, Câmiu'l-Ahkâmi'l-Kur'ân, 20 Cilt, Daru'lFikr, trs., y.y.

MÂTURIDİ, Ebu Mansur, Kitâbu't-Tevhid, thk. Muhammed Aruçi, T.D.V. Yayınları, Ankara, 2003

MÂTURIDİ, Ebu Mansur, Te'vilâtu'l-Kur'ân, thk. Ahmed Vanlıoğlu, 17 Cilt, Daru'l-Mizan Yayınları, İstanbul, 2005

MEVDUDİ, Seyyid Ebü'1-A'la, Tefhimu'l-Kuran,trc. Muhammed Han Kayani, cilt 1, İnsan Yayınları, İstanbul, 1986

OYMAK, İskender, "Akçadağ ve Çevresinde Kutsal Mekan Anlayışı", Fırat Üniversitesi İlahiyat Fakültesi Dergisi, Sayı 5, Elazığ, 2000 
ÖZ, Mustafa, "Kerbela" maddesi, TDV İslam Ansiklopedisi, TDV Yayınlar1, cilt 25, 2002

ÖZER, Salih, "İslam Düşüncesinde Kutsal (Zaman) Kavramı", İslami Araştırmalar Dergisi, cilt 18, say1 3, 2005

POLAT, Emanullah, "Kutsalın Psikolojik Boyutu", Bingöl Üniversitesi İlahiyat Fakültesi Dergisi, sayı 3, 2014

SABUNI, Muhammed Ali, Safvetü't-Tefasir, Trc.Sadrettin GümüşNedim Yılmaz, cilt VI, Ensar Neşriyat, İstanbul, 1992

SELÇUK, Ali, "Dede Mezarindaki Sir: Ziyaret Fenomeni ve Kutsalın Tezahürleri", Türk Kültürü ve Hacı Bektaş Veli Araştırma Dergisi, say1 56, 2010

TOPÇUOĞLU, Ali Aslan, "Kuran ve Sünnete Göre İfade Özgürlüğü ve Kutsal Değerlere Saygı", İslam Hukuku Araştırmaları Dergisi, say1 7, Nisan 2006

Türk Dil Kurumu, Türkçe Sözlük, TDK Yayınları, II Cilt, Ankara, 1988

VERGOTE, Antoine, "Kutsal", çev.Halife Keskin-Asim Yapıcı, Çorum Üniversitesi İlahiyat Fakültesi Dergisi, Cilt 2, Sayı 2, TemmuzAralık 2002

YAVUZ, Ömer Faruk, "Kuran'da Kutsal Mekan, Zaman ve Eşya Kavramlarının Sembolik Değeri", Cumhuriyet Üniversitesi İlahiyat Fakültesi Dergisi, sayı-X/2, 2006

YAZIR, Elmalı1ı Hamdi, Hak Dini Kuran Dili, Eser Neşriyat Yayınları, cilt VII, İstanbul, 1979

YEĞìn, Hüseyin, "Din Psikolojisi Açısından Kutsal Mekan İnsan İlişkisi", Harran Üniversitesi İlahiyat Fakültesi Dergisi, Y1l 17, say1 27, Ocak-Haziran 2012

YILDIRIM, Suat, Kuran'da Uluhiyet, Kayıhan Yayınları, İstanbul, 1987 
YILDIZ, Beyza, İnsanın Kutsallaştırılması ve Kuran'ı Kerim, (basılmamış yüksek lisans tezi), İstanbul, 2010

YÖRÜKAN, Yusuf Ziya, Müslümanlıktan evvel Türk Dinleri Şamanizm: Şamanizm'in Diğer Dinler ve Aleviler Üzerinde Etkileri, Yol Yayınları, Ankara, 2005

YUNUS, Hüseyin, Tekfir Meselesi, Ahenk Yayınları, Van, t.y.

http://www.tdk.gov.tr/index.php?option=com_gts\&arama=gts\&gui $\underline{\mathrm{d}=\text { TDK.GTS.56bb43fa0383b6.10835889 }}$ 